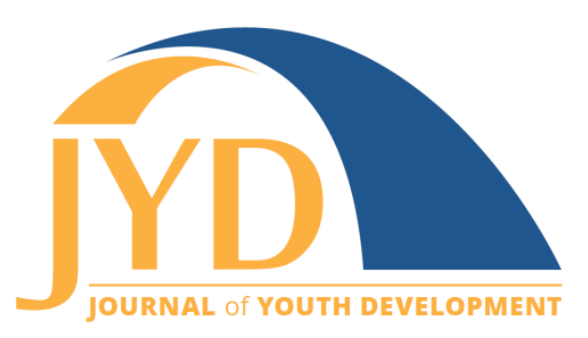

http://jyd. pitt. edu/ | Vol. 14 Issue 3 DOI 10.5195/jyd.2019.720 | ISSN 2325-4017 (online)

\title{
Life Skill Development and Financial Impact Associated With a Youth Livestock Sales Program
}

\section{Holly Evans}

Mississippi State University

hce36@msstate.edu

\section{Dean Jousan}

Mississippi State University djousan@ads.msstate.edu

\section{Erdogan Memili}

Mississippi State University

em149@ads.msstate.edu

\section{Leigh Beckman}

Mississippi State University

jbeckman@math.msstate.edu

\section{Molly Nicodemus}

Mississippi State University

mnicodemus@ads.msstate.edu

\begin{abstract}
The Sale of Junior Champions is a premier livestock auction and youth scholarship program held at Dixie Nationals as a part of Mississippi's junior livestock program. The sale is open to 4-H and FFA members who qualified their livestock at the annual Dixie National Junior Round-Up. While youth livestock sales programs are commonly found at state and county fairs throughout the United States, demographic information and information concerning financial and life skill impacts of the program on participants is limited. Therefore, a survey instrument for the 2018 sale was designed to determine how the event has impacted the financial burden of continued education and life skill development of youth participants. Paper and electronic surveys were distributed during and after the event. Responses $(\mathrm{n}=176)$ reflected a diverse group of participants including 4-H/FFA members (22\%), parents of youth (22\%), volunteers (21\%), Extension employees/FFA advisors (22\%), sale buyers/sponsors (12\%), and others (2\%). Most participants (45\%) were older (40-60 years old). Almost half of the respondents (43\%) had attended the
\end{abstract}

(c) $\mathbf{E Y}$ New articles in this journal are licensed under a Creative Commons Attribution 4.0 License. This journal is published by the University Library System, University of Pittsburgh and is cosponsored by the University of Pittsburgh Press. The Journal of Youth Development is the official peer-reviewed publication of the National Association of Extension 4-H Agents and the National AfterSchool Association. 


\section{Assessment of a Youth Livestock Sales Program}

sale 6 or more times, while $10 \%$ were first-time attendees. A driving force for attendance appeared to be the scholarships as 33\% received or had a youth receiving a scholarship. Program participation promoted improvement in all life skills measured. Future educational goals in youths were reported to be positively impacted by sale participation ( $\mathrm{p}<0.001$ ). Understanding of sale participant demographics and financial and life skill impacts will assist in program justification, future program growth, and identifying groups where participation can be strengthened.

Key words: youth scholarship programs, livestock sales, youth life skills, 4-H, FFA

\section{Introduction}

Youth programs such as 4-H and FFA were established decades ago in order to help youth continue to develop various life skills (Lockman, 2017). These programs are designed to engage youth through hands-on learning in a non-traditional manner. Involvement in 4-H and FFA programs gives youth the ability to take on the responsibility of their own project to gain skills and knowledge that will benefit them as young adults (Ward, 1996; Goodwin, 2010; Rose et al., 2016).

Youth livestock sales programs are not uncommon throughout the United States as they can be found at most state and county fairs each year (Kreutz, 2013). As for Mississippi, the Dixie National Junior Round-Up (DNJR) is the premier junior market animal show where youth exhibit market animals from which the Champion and Reserve Champion animals are selected to be auctioned through the Sale of Junior Champions (Jousan, 2018). Both 4-H and FFA contestants exhibit their livestock in the largest junior market livestock show in Mississippi. The Champions and Reserve Champions of the Junior Market steer, lamb, swine, Mississippi bred barrow, and goat shows are singled out for a special tribute at the Dixie National Livestock Show and are eligible for the Sale of Junior Champions. The number animals that qualify for the sale range between two and 12 animals per Junior Market Show. In addition to these animals, if they are not one of the regular show Champions or Reserve Champions, the Overall Grand and Reserve Grand Champion Mississippi bred market steers, lambs, and goats are eligible for the sale with two animals per type of livestock qualifying. Thus, a total of 42 to 48 animals typically qualify for the Sale of Junior Champions.

This sale has steadily grown over the last 49 years, having grossed over $\$ 100,000$ in sales for 24 years consecutively and generating $\$ 6.89$ million in total sales. In addition, the scholarship program has grown from awarding a single $\$ 1,000$ scholarship 26 years ago to having provided a total of $\$ 832,700$ in scholarship funds to support the education of Mississippi youth (Jousan, 


\section{Assessment of a Youth Livestock Sales Program}

2018). When the exhibitor's animal is sold, he or she receives $75 \%$ of the sale price of their animal. The Sale of Junior Champions committee retains $25 \%$ of the sale price, which is then used for scholarship funds (20\%) and for expenses such as promotion of the sale (5\%). The following are the three different ways a youth may be rewarded a scholarship: (a) be a senior in high school that did not have an animal qualify for the sale, (b) be a winner of the Premier Exhibitor Contest, or (c) have a Supreme Breeding Animal.

High school seniors that show livestock at Dixie Nationals, but do not qualify an animal for the sale have an opportunity to win a $\$ 1,500$ scholarship. In 2018 , the committee presented 39 youth with these scholarships totaling $\$ 58,500$. To be eligible, youth have to show an animal at that year's DNJR (breeding or market animal). They submit an application with the following aspects of the application weighted accordingly in the scholarship selection: financial need (35\%); involvement in animal projects (35\%); education/grades (15\%); and overall impression (15\%). Three members of the Sale of Junior Champions committee score the applications and determine which youths are deserving of these scholarships.

On the other hand, winners of the Premier Exhibitor Scholarship are youths who submit an application in whatever species they show (beef cattle, dairy cattle, meat goat, dairy goat, sheep, and/or swine), go through questions at stations that pertain to their species, take an exam, go through an interview, and then earn points in showmanship and with their animal in its respective class while showing. These scholarships are $\$ 2,000$ each. It is possible that a winner of the Premier Exhibitor Scholarship could have a Supreme Animal too, and thus, could win two scholarships.

Supreme Animal Scholarship winners earn $\$ 1,500$ for earning a supreme title. These breeding animals are not included in the sale. The title of Supreme Champion in one of the following categories earns a youth exhibitor this scholarship: beef heifer, beef bull, dairy cattle female, senior dairy goat female, commercial beef heifer, and commercial meat goat doe.

While these scholarship opportunities are attractive to high school age youths as they start their college search, the benefits of these programs go beyond financial impact (Kreutz, 2013). 4-H and FFA programs provide an outlet for youth to experience a plethora of exciting, yet educational opportunities that assist in building life skills (Ward, 1996; National 4-H Council, 2013; Harris, Stripling, Stephens, \& Loveday, 2016). Youth are presented with choices of projects and activities to participate in such as youth livestock sales programs so that they may explore various areas of interest as they build these skills. Previous research has revealed that 


\section{Assessment of a Youth Livestock Sales Program}

4-H program participation has impacted life skill development and has prepared young adults to succeed (Ratkos \& Knollenberg, 2015). Furthermore, a study by Boleman, Cummings, and Briers (2004) revealed that parents of youth that were involved in 4-H livestock projects noticed enhancement of life skill development related to participation. The longer children were involved in their projects, the more likely the children were to develop important skills for life.

Nevertheless, participation is a limiting factor for these youth programs to flourish, and with the ever-changing diversity within the population being recruited for these programs, recruitment becomes even more challenging today (LaVergne, 2013; Martin \& Kitchel, 2014). Furthermore, along with the difficulty of recruitment, events such as a youth livestock sales program require a large amount of planning, organizing, and monetary input. Thus, it is necessary to ascertain the value and effect that programs such as the sale have on youth participants, family members, and community members. This information helps committee members and/or event organizers evaluate the efficacy of the program and determine its value, outside of just dollars and cents, and how it may be changed for the better.

In the end, while participation numbers and scholarship dollars are recorded for these programs, to date, documentation of the types and extent of participation associated specifically with youth livestock sales programs and the impact of this type of program on youth and others involved with these events are lacking. Therefore, the objective of this study was to examine participation and the broader impacts of a youth livestock sales program, the Sale of Junior Champions, through the application of a survey instrument.

\section{Methods}

\section{Survey Participants}

The Sale of Junior Champions is held annually at the Dixie National Junior Round-Up. The 2018 sale was held in Jackson, Mississippi during the month of February. Youth livestock exhibitors for the sale included both 4-H and FFA members. Along with youth sale exhibitors, other 4-H and FFA members attended the sale to receive scholarships associated with the youth livestock sales program. In addition, sale attendees included buyers of the sale animals, sale sponsors, parents of youth exhibitors and/or scholarship recipients, sale volunteers, faculty and staff associated with Mississippi State University, and local community members. Sponsors of the sale were defined as those businesses or individuals who were not buyers of sale animals, but donated funds directly to the scholarship program. These monies were $100 \%$ transferred to the 


\section{Assessment of a Youth Livestock Sales Program}

scholarship program, and then were combined with a $20 \%$ commission taken from the sale of each animal. Buyers were defined as individuals and businesses that put forth money toward the purchase of a sale animal at the auction. Exhibitors were those youth that qualified a Champion or Reserve Champion animal. Exhibitors could have qualified multiple animals in the same species or across species in the same year. Exhibitors were, however, limited in how many animals were shown. They could have three market animals per species as long as one animal was Mississippi bred.

During the 2018 Sale of Junior Champions, paper copies of the survey were distributed to all sale participants and attendees in which survey participants were allowed to complete the survey throughout the duration of the event. A booth was set up at the entrance of the auction facility where the sale took place. Mississippi State University employees handed out the paper survey at the booth and answered questions about the sale and the survey. The booth was staffed by at least two employees for at least 30 minutes before and after the sale and during the sale. Survey participation was voluntary. A total of 100 copies of the survey were available at the booth for distribution.

In addition to the paper format, an online format of the survey was developed for participants and shared via social media platforms and email. The survey was set up through Survey Monkey with the link sent out utilizing an email list consisting of all county extension offices' employees and FFA advisors throughout the state of Mississippi. In addition, the email was sent to all 30 members of the Sale of Junior Champions committee. During the 6-week period after the conclusion of the 2018 sale, a survey link was available on the Mississippi 4-H Livestock Facebook page and an email reminder for survey participation was sent out three times.

\section{Survey Instrument}

The survey instrument was reviewed and approved by the Institutional Review Board for the Protection of Human Subjects prior to survey distribution. The questions for the survey were developed from input given by Mississippi State University faculty and staff including Extension agents, volunteers for the various youth programs, and previous participants for these youth programs. Question development and survey implementation followed principles from the Tailored Design Method (Dillman, 2000). Prior to the 2018 sale, the survey instrument was evaluated for the relative nature of the questioning and the clarity of questions and answers by a panel of four experts. These experts consisted of individuals that have participated in 4-H and/or FFA livestock programs as either an alumnus of these programs, producer involved with 


\section{Assessment of a Youth Livestock Sales Program}

these programs, and/or University faculty/staff member with Extension responsibilities. Through feedback from these individuals minor changes were made to the survey instrument to improve the clarity of questioning utilizing language appropriate to the target audience prior to survey distribution.

Questions on both the paper and online formats of the survey instrument were identical and are displayed in Table 1. The survey instrument gathered demographic information in addition to participation information and perceived benefits of participation to those involved in the youth livestock sales program.

Table 1. Questions From the 2018 Sale of Junior Champions Survey Instrument

\begin{tabular}{|c|c|c|}
\hline $\begin{array}{l}\text { Question } \\
\text { number }\end{array}$ & Survey question & $\begin{array}{l}\text { Number of } \\
\text { answers } \\
\text { possible }\end{array}$ \\
\hline 1 & How old are you? & 4 \\
\hline 2 & What is your gender? & 2 \\
\hline 3 & $\begin{array}{l}\text { How many Dixie National Sale of Junior Champions events have you } \\
\text { attended or participated in? }\end{array}$ & 5 \\
\hline 4 & $\begin{array}{l}\text { How did you hear about the Dixie National Sale of Junior Champions } \\
\text { event? }\end{array}$ & 7 \\
\hline 5 & $\begin{array}{l}\text { How has the Dixie National Sale of Junior Champions directly impacted } \\
\text { you or your child? }\end{array}$ & 6 \\
\hline 6 & $\begin{array}{l}\text { How have you financially supported scholarship funds for the Dixie } \\
\text { National Sale of Junior Champions? }\end{array}$ & 4 \\
\hline 7 & $\begin{array}{l}\text { If you bought livestock from the Dixie National Sale of Junior Champions, } \\
\text { what is the total amount you have spent on livestock from the Sale? }\end{array}$ & 8 \\
\hline 8 & $\begin{array}{l}\text { If you or your child participated in the Dixie National Sale of Junior } \\
\text { Champions, how many animals did you or your child sell through this } \\
\text { event during your time of showing livestock? }\end{array}$ & 5 \\
\hline 9 & $\begin{array}{l}\text { If you or your child participated in the Dixie National Sale of Junior } \\
\text { Champions, how much money in scholarship funds have you or your child } \\
\text { received through the Sale? }\end{array}$ & 6 \\
\hline
\end{tabular}


Table 1 (continued)

\begin{tabular}{|c|c|c|}
\hline $\begin{array}{l}\text { Question } \\
\text { number }\end{array}$ & Survey question & $\begin{array}{l}\text { Number of } \\
\text { answers } \\
\text { possible }\end{array}$ \\
\hline 10 & $\begin{array}{l}\text { If you or your child participated in the Dixie National Sale of Junior } \\
\text { Champions, how much investment did your family put into raising and } \\
\text { developing your animals to show? }\end{array}$ & 8 \\
\hline 11 & $\begin{array}{l}\text { If you or your child has sold an animal(s) in the Dixie National Sale of } \\
\text { Junior Champions, what type of livestock did you or your child show? }\end{array}$ & 6 \\
\hline 12 & $\begin{array}{l}\text { If you or your child participated in the Dixie National Sale of Junior } \\
\text { Champions, has the sale positively impacted you or your child's goals for } \\
\text { college and future education? }\end{array}$ & 5 \\
\hline 13 & $\begin{array}{l}\text { If you or your child participated in the Dixie National Sale of Junior } \\
\text { Champions, has the Sale positively impacted you or your child's career } \\
\text { goal? }\end{array}$ & 5 \\
\hline 14 & $\begin{array}{l}\text { How long have you or your child been involved in Mississippi Youth } \\
\text { Livestock Programs such as } 4-\mathrm{H} \text { or FFA? }\end{array}$ & 5 \\
\hline 15 & $\begin{array}{l}\text { What has been your role associated with Mississippi Youth Livestock } \\
\text { Programs? }\end{array}$ & 7 \\
\hline 16 & $\begin{array}{l}\text { Below is a list of life skills. For each life skill, indicate how participation in } \\
\text { Mississippi Youth Livestock Programs such as the Dixie Nationals Sale of } \\
\text { Junior Champions may have improved your or your child's abilities } \\
\text { associated with that life skill. Only check one box for each life skill. }\end{array}$ & 5 \\
\hline
\end{tabular}

Of the 16 forced-choice questions, five were partially closed questions allowing for an "other" option with a space for writing in details if there was not an answer that matched the respondent's needs. The last question in the survey used a closed question with ordered choices to have the participants evaluate their level of improvement in the following life skills: decision making, time management, problem solving, goal setting, building friendships, professional networking, public speaking, respect, effective listening, and financial responsibility. Cronbach's alpha was applied to determine the reliability of the survey instrument with the results of the reliability analysis determined to be acceptable $(a=0.80)$. 


\section{Assessment of a Youth Livestock Sales Program}

\section{Data Analysis}

Descriptive statistics was utilized for each question with the number of responses totaled into respective groups based on the answer selection and percentages generated per answer response. A binomial test was performed for questions 12 and 13 . Significance was denoted at a $p$-value less than 0.001 .

\section{Results}

\section{Demographics}

The participants in this study ( $n=176$ completed the survey; 131 online surveys completed and 45 paper surveys completed) were characterized into four age groups. Of the four age groups, $12 \%$ were in the 18 to 25 age group, $26 \%$ were in the 25 to 40 age group, $45 \%$ were in the 40 to 60 age group, and the remaining $16 \%$ were outside of the age groups listed. As for gender, the majority (54\%) were male.

\section{Involvement}

According to survey responses, sale participation reflects a diverse group of attendees including 4-H/FFA members (22\%), parents of participating youths (22\%), volunteers (21\%), Extension employees/FFA advisors (22\%), buyers/sponsors (12\%), and others (2\%). The youth livestock sales program appears to encourage dedicated annual participation as $43 \%$ of the respondents had attended the Sale of Junior Champions six or more times, while only $10 \%$ of responders were first-time sale attendees.

Attendees of the event demonstrated various avenues of support of the event. From a financial standpoint, respondents reported that they bought livestock (31\%), sponsors that donated funds $(8 \%)$, or supported the sale in another manner (8\%) such as sponsoring the pre-sale reception or promoting the sale participants. Those who indicated they supported the sale by purchasing animals (i.e., "buyers") either this year or in previous years were broken into categories based on the amount they spent on the animal(s). The greatest number of animal buyers spent under $\$ 500$ (Figure 1 ). These values vary because multiple buyers may combine funds to purchase one or more animals at the sale.

The youth exhibitor's monetary investment in their animals varied (Figure 1). The investments made by youth exhibitors accounts for their spending over the course of their project. Possible 


\section{Assessment of a Youth Livestock Sales Program}

expenses include feed costs, health care, transport, and show fees. Monetary investment varies based on several factors such as feed costs, facility use or rental, animal purchase costs, livestock species, and medical costs. As for the sale, youth exhibitors' financial investment ranged from $\$ 500$ to over $\$ 20,000$. This amount included this year and any previous year of participation for the youth. When comparing family investments, the largest category/range was those families spending over $\$ 20,000$ on their animal projects.

Figure 1. Percentage of Monetary Spending of Livestock Animal Sale Buyers Compared to Percentage of Monetary Investment by Youth Raising Livestock Animals for the Sale

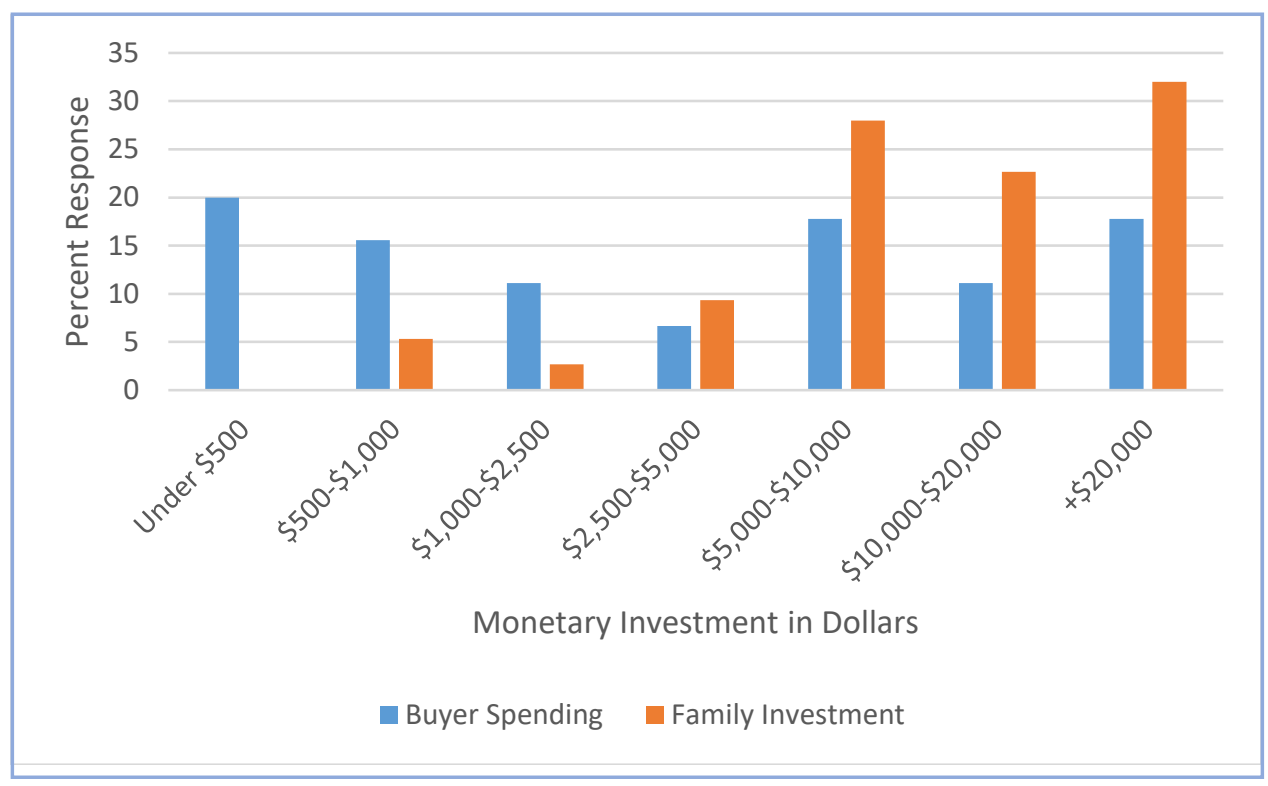

\section{Scholarship and Youth Development}

Approximately $33 \%$ of the participants in the sale were directly impacted by receiving a scholarship or being the parent of youth who received a scholarship. Of the 75 respondents that received scholarship funding or were the parents of scholarship recipients, during their youth livestock show career (ages $8-18$ ), $4 \%$ received under $\$ 1,000,28 \%$ received $\$ 1,000$ to $\$ 2,000$, $17 \%$ received $\$ 2,000$ to $\$ 3,000$, $9 \%$ received $\$ 3,000$ to $\$ 5,000$, and $41 \%$ received over $\$ 5,000$. Because some scholarships are awarded to Supreme Champion Breeding Animals or for winning educational contests associated with the youth livestock show and sale program, it is possible that youth received multiple scholarships of varying amounts over their youth show career. 
Participants were asked if they felt like they or their child's career goals had been positively impacted by the Sale of Junior Champions. Of the 91 people who answered Question 13 (response rate $=52 \%$ ), $97 \%$ of respondents said that they or their child was positively impacted $(p<0.001)$. The majority of participants felt that they or their child's future collegiate and/or educational goals (Question 12) had been positively impacted by their participation in the sale $(p<0.001)$.

\section{Life Skills Development}

Question 16 (response rate $=59 \%$ ) asked respondents to reflect on the extent to which their participation or their child's participation in a youth livestock sales program impacted the life skills of decision making, time management, problem solving, goal setting, friendship building, professional networking, public speaking, respect, effective listening, and financial responsibility. Figure 2 illustrates respondents' answers to Question 16. Friendship building showed the strongest improvement with $77 \%$ of the responses indicating a "strong improvement" of that skill. Public speaking had the highest percentage of "not improved" responses (4\%), while goal setting and effective listening were the only skills that had no respondents report "not improved". "Large improvement" was the preferred choice for respondents for all skills followed by "good improvement". 
Figure 2. Participants' Life Skill Development Through a Youth Livestock Sales Program

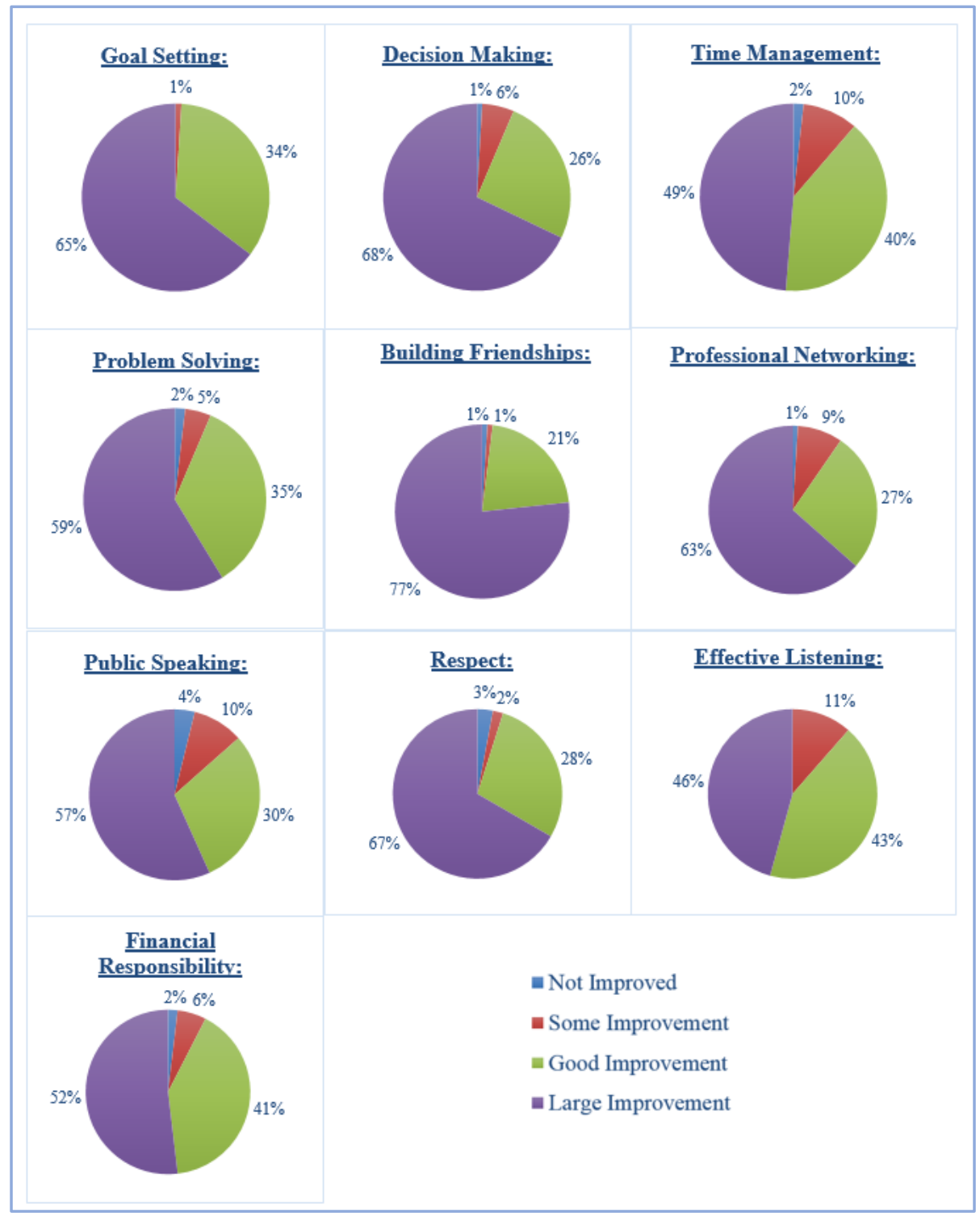

\section{Discussion}

\section{Limitations of the Survey Instrument}

Due to the time and money needed to develop and carry out youth programs, there is an urgency by those overseeing these programs that some type of justification is available to continue funding and orchestrating these programs. While number of participants, scholarships awarded, funds collected, and overall costs are traditionally recorded for these youth programs, 


\section{Assessment of a Youth Livestock Sales Program}

more thorough feedback on the impact of these programs, both financially and on participant development, has been lacking for more specialized programs like youth livestock sales programs. Often coordinators of these youth programs will visit with participants and families in person to get input on these programs, but the application of survey instruments has proven to be a useful tool for documenting specifics on program benefits and weaknesses (Taylor-Powell, Steele, \& Doughah, 1996). Therefore, a survey instrument for a youth livestock sales program, the Sale of Junior Champions, was designed and implemented to assess participant involvement and impact, both financially and in skill development of the youth participants.

The survey instrument in this study was distributed in both paper and online formats to those that were involved in some aspect of the 2018 Sale of Junior Champions. Offering multiple formats of the survey allowed for a greater range of participants, increasing response numbers (Dillman, 2000). The recruitment of participants can be a limiting factor in survey studies (Parker, Manan, \& Urbanski, 2012). In addition, with the goal of maximizing respondent numbers and knowing the diversity of participants that would be targeted, survey questions were developed to be less focused. Thus, more specific conclusions directed towards a certain population or particular aspects of the sale are unavailable at this time. Furthermore, the number of questions in the survey was limited in order to assist in attracting participants (Dillman, 2000), but this approach also restricted the ability to move into more detailed questioning. Nevertheless, despite these limitations, the use of multiple survey formats, less specific survey questions, and limited number of survey questions are recommended for other youth programs in the initial stages of applying a survey instrument for program assessment in order to increase survey participant numbers.

\section{Sale Participation}

With today's technology, youth are more prone to stay inside the home interacting with their electronics than working outside with their animals (Palmer, McCarthy, Perkins, Borden, \& DiNallo, 2018). Thus, one goal of this survey was to collect feedback as to what was the driving force for those participating in youth livestock sales programs. A driving force for sale attendance appeared to be the scholarships, as 33\% received or had a child receive a scholarship, while $32 \%$ attended to present qualified sale animals, which resulted in the youth receiving monies for the sale of their animal. Specific questions, however, concerning motivation for participation were not directly asked in the survey instrument. Nevertheless, as Figure 1 demonstrates, while the $\$ 1,500$ scholarships associated with this sale may be linked with participation, the monies invested by families for participation well exceeded the return of 


\section{Assessment of a Youth Livestock Sales Program}

the scholarships gained, thus, suggesting intangible returns such as development of life skills. According to Arnold, Meinhold, Skubinna, and Ashton (2007), youth participants in county 4-H fairs did not report sale of their animal as the highest motivator for participation, but instead reported such things as "having fun," "achieving goals," "spending time with friends," and "teamwork," offering insight to what we refer to as these intangible returns for participation.

In addition, while money appeared to be linked with participation, only $15 \%$ of survey participants attributed their attendance to being a sale buyer and/or sponsor. Nevertheless, these individuals are valuable for future programs and for the broadening of youth participation. Likewise, many of the write-in responses recommended increasing the funding for the program and scholarships. Weikert, Hoover, Radhakrishna, and Swinker (2015) performed a similar study that included questions covering limiting factors for respondents and their participation in 4-H programs. The biggest limiting factor for participants was the cost of participation. Again, as seen in Figure 1, cost of participation well exceeded the value of the scholarships received, and thus, the expansion of scholarship opportunities will help to offset the cost of participation in this sale program.

\section{Life Skills Development and Youth Programs}

Previous studies have indicated personal growth and life skill development through the participation in specific aspects of 4-H programing (Anderson \& Karr-Lilienthal, 2011; Davis, Stripling, Stephens, \& Loveday, 2016; Haas, Mincemoyer, \& Perkins, 2015). This, however, was the first survey to be administered at this event, thus the focus of this survey instrument was to determine the broad impact of participation in a youth program over a focused timeframe. Similar to Harris et al. (2016), a gain in development for all of the life skills evaluated was attributed to the youth livestock program. While neither study describes changes that may have been seen from year to year or changes that individuals may experience from participating in different aspects of the event, the results give a broad look at the impact of participation on youth development. Particularly, self-reflection of life skill development for a youth helps in future career goal achievement, redirecting the focus in youth livestock programs away from just the monetary value of the sale of the animal (Lerner, Lerner, \& Phelps, 2008). This is of particular importance with the cost of participation outweighing the return.

While development of certain life skills takes years (Lerner et al., 2008), this survey instrument is a snapshot of a particular year and how participating in this sale affected individuals. While this approach is not uncommon (Deaver \& Probert, 2016; Harris et al., 2016), future survey 


\section{Assessment of a Youth Livestock Sales Program}

studies should look at longitudinal studies as they assist in tracking the variations in skill development and perceptions moving data beyond immediate program effectiveness towards the quantification and qualification of long-term impact (Workman \& Scheer, 2012). Nevertheless, one must also take into consideration that this type of self-reporting study is prone to biases due to subjectivity of the respondent. This can lead a respondent to distort one's answers to enhance self-esteem or favor one's self in some aspect (Reifenberg, 1986). In addition to this, a youth may respond differently to the survey than his or her parent or guardian who is responding on the youth's behalf. This survey instrument allowed for both youths and parents of these youths to evaluate life skill development of the youths, and thus, the combined responses may show variability related to what the youths perceive versus what their parents perceive. This survey study did not look at the specific differences between youths and their parents in these answers, and while this type of comparison would be of interest in discussing the variability in viewpoints of those involved with these programs, combining of the perspectives of the various groups involved in this youth program was designed to determine a collective impact of these programs, not specific to one group.

\section{Further Development of Survey Instruments}

The data produced by this survey instrument gives insight not only to this youth livestock sales program, but to other similar programs concerning program impact and insight on areas for development including recruitment of future sponsors and buyers to increase scholarship opportunities. However, for future survey studies associated with this or similar youth programs, survey data can be greatly elevated in validity and strength if a secondary study is conducted after adjustments are made to the event based on the data that the primary study provided. There are few secondary studies in this field, and yet, it is helpful to conduct research in this manner to evaluate the efficacy of the original study such that more statistical analysis may be completed.

Similarly, pre-event surveys are useful in obtaining a baseline to which to compare post-event results, such as evaluating the youths' life skills prior to and after participation in an event (Rockwell \& Kohn, 1989). Junge, Manglallan, and Raskauskas (2003) utilized pre- and postevent survey instruments to evaluate how after-school programs affect the development of life skills. They found that the use of pre- and post-program survey instruments allowed for the demonstration of life skill development over time and determination of how specific life skills differed in relation to other factors such as gender, age, and ethnic background. While the current study did not perform a pre-event survey, the question pertaining to life skills asked 


\section{Assessment of a Youth Livestock Sales Program}

survey participants to assess the impact of the sale on life skills, and thus gave a perceived effect of the development of life skills over time. This approach is similar to previous studies evaluating youth livestock programs (Deaver \& Probert, 2016; Harris et al., 2016).

\section{Scholarship Impact for Youth Participants}

The perceived improvements and impacts that this program has on the participants demonstrate the necessity and importance of youth programs such as this sale. These programs are demanding in terms of organization and execution, but they are vital to the development of life skills and aid in directing the educational path of youth. About $33 \%$ of the children involved in the 2018 sale received scholarships and $41 \%$ of the participants received over $\$ 5,000$ in scholarship funds throughout their participation. Through the monies received by participants, they learned the value of the livestock industry giving them a stepping stone into a potential career in the livestock industry. In addition, the contacts that these youths make while participating in these programs will be of use if they decide to make a career in the livestock industry (Deaver \& Probert, 2016).

While this study did not focus on the specifics concerning the impact of this program on career selection, the positive response on career goal development through participation in the sale suggests a potential for continued involvement in the livestock industry. According to Williams, Thompson, Taylor, and Sanders (2010), long-term youth involvement in 4-H programs aids in career choice of youth participants. However, the study goes on to suggest these programs may not provide adequate career awareness that will need to be supplemented by other external programs. Nevertheless, the development of life skills through these youth livestock programs as seen in the current study may help nourish the proactive nature of the youth to search out the needed career awareness for being successful in their career selection (Deaver \& Probert, 2016).

\section{Concluding Statement}

The information that has been gathered from this survey instrument will help guide those involved with this type of youth livestock sales program in their future decisions for program development. The multi-facet approach to this survey instrument to investigate both the financial and youth developmental impacts will assist in program betterment by finding balance between dollars spent and the return seen in the development of skills that will lay the foundation for the future success of youth participants. In the end, this survey instrument and 


\section{Assessment of a Youth Livestock Sales Program}

the results can serve as guidance for other county and state programs wanting to do similar youth programs or utilize comparable survey instruments to evaluate their own youth livestock sales programs.

\section{References}

Anderson, K. P., \& Karr-Lilienthal, L. (2011). Influence of 4-H horse project involvement on development of life skills. Journal of Extension, 49(5). Retrieved from http://www.joe.org/joe/2011october/iw2.php

Arnold, M. E., Meinhold, J. L., Skubinna, T., \& Ashton, C. (2007). The motivation for and developmental benefits of youth participation in county 4-H fairs: A pilot study. Journal of Extension, 45(6). Retrieved from https://www.joe.org/joe/2007december/rb5.php

Boleman, C. T., Cummings, S. R., \& Briers, G. E. (2004). Parents' perceptions of life skills gained by youth participating in the 4-H beef project. Journal of Extension, 42(5). Retrieved from https://www.joe.org/joe/2004october/rb6.php

Davis, T. K., Stripling, C. T., Stephens, C. A., \& Loveday, H. D. (2016). Understanding life skills gained from and reasons for youth participation in the Tennessee 4-H sheep skillathon. Journal of Extension, 54(4). Retrieved from http://www.joe.org/joe/2016august/pdf/JOE_v54_4rb7.pdf

Deaver, K., \& Probert, T. (2016). The value of 4-H judging teams- Missouri dairy judging alumni survey. Journal of Extension, 54(1). Retrieved from https://joe.org/joe/2016february/pdf/JOE_v54_1rb8.pdf

Dillman, D. A. (2000). Mail and internet surveys: The tailored design method. New York, NY: John Wiley \& Sons.

Goodwin, J. (2010). Study of Colorado 4-H alumni demonstrates the importance of 4-H. (Impact report.) Retrieved from Colorado State University Extension website: https://extension.colostate.edu/docs/comm/impact/4h-alumni.pdf

Haas, B. E., Mincemoyer, C. C., \& Perkins, D. F. (2015). The effects of age, gender, and 4-H involvement on life skill development. Journal of Extension, 53(3). Retrieved from http://www.joe.org/joe/2015june/pdf/JOE_v53_3a8.pdf

Harris, J. M., Stripling, C. T., Stephens, C. A., \& Loveday, H. D. (2016). Life skill development of youth participants of the Tennessee 4-H beef skillathon. Journal of Youth Development, 11(1). Retrieved from https://jyd.pitt.edu/ojs/jyd/article/viewFile/436/420

Jousan, D. (2018, March). 4-H Animal Lines. Retrieved from http://extension.msstate.edu/newsletters/4hanimal-lines-newsletters/2018/march-2018-4-h-animal-lines

Junge, S., Manglallan, S., \& Raskauskas, J. (2003). Building life skills through afterschool participation in experimental and cooperative learning. Child Study Journal, 33(3), 165-174. Available at 
Journal of Youth Development | http://jyd.pitt.edu/ | Vol. 14 Issue 3 DOI 10.5195/jyd.2019.720

\section{Assessment of a Youth Livestock Sales Program}

https://go.galegroup.com/ps/anonymous?id=GALE\%7CA116924602\&sid=googleScholar\&v=2.1\&i $\mathrm{t}=\mathrm{r} \&$ linkaccess $=$ abs\&issn $=00094005 \& \mathrm{p}=\mathrm{AONE} \& \mathrm{sw}=\mathrm{w}$

Kreutz, D. (2013, April 17) UA 4-H program benefits Arizona youth, economy. UA News. Retrieved from https://uanews.arizona.edu/story/ua-4-h-program-benefits-arizona-youth-economy

LaVergne, D. (2013). Diversity inclusion in 4-H youth programs: Examining the perceptions among West Virginia 4-H youth professionals. Journal of Extension, 51(4). Retrieved from https://joe.org/joe/2013august/a1.php

Lockman, C. (2017, September 26). 4-H and FFA set youth up for success. Farm Flavor. Retrieved from https://www.farmflavor.com/north-dakota/4h-ffa-set-youth-up-for-success/

Martin, M. J., \& Kitchel, T. (2014). Barriers to participation in the National FFA Organization according to urban agriculture students. Journal of Agricultural Education, 55(1), 120-133.

National 4-H Council. (2013). The positive development of youth: Comprehensive findings from the 4-h study of positive youth development (Factsheet). Retrieved from https://4-h.org/wpcontent/uploads/2016/02/4-H-Study-of-Positive-Youth-Development-Fact-Sheet.pdf

Palmer, L. A., McCarthy, K. J., Perkins, D. F., Borden, L. M., \& DiNallo, J. M. (2018) Online child's health assessment tool for obesity prevention programming. Journal of Youth Development, 13(3), 237258. doi:10.5195/jyd.2018.599

Parker, M. J., Manan, A., \& Urbanski, S. (2012). Prospective evaluation of direct approach with a tablet device as a strategy to enhance survey study participant response rate. BMC Research Notes, 5(1), 605-610. doi:10.1186/1756-0500-5-605

Ratkos, J., \& Knollenberg, L. (2015). College Transitions study shows 4-H helps youth prepare for and succeed in college. Journal of Extension, 53(4). Retrieved from http://www.joe.org/joe/2015august/pdf/JOE_v53_4a7.pdf

Reifenberg, R. J. (1986). The self-serving bias and the use of objective and subjective methods for measuring success and failure. Journal of Social Psychology, 126(5), 627.

Rockwell, S. K., \& Kohn, H. (1989). Post-then-pre evaluation: Measuring behavior change more accurately. Journal of Extension, 27(2), 19-21. Retrieved from https://www.joe.org/joe/1989summer/a5.php

Rose, C., Stephens, C. A., Stripling, C., Cross, T., Sanok, D. E., \& Brawner, S. (2016). The benefits of FFA membership as part of agricultural education. Journal of Agricultural Education, 57(2), 33-45.

Taylor-Powell, E., Steele, S., \& Douglah, M. (1996). Planning a Program Evaluation (Press release). Retrieved from University of Wisconsin Cooperative Extension website: http://learningstore.uwex.edu/assets/pdPlanning a program evaluation.

Ward, C. K. (1996). Life skill development related to participation in 4-H animal science projects. Journal of Extension 34(2). P. 40-43. Retrieved from https://www.joe.org/joe/1996april/rb2.php 
Journal of Youth Development | http://jyd.pitt.edu/ | Vol. 14 Issue 3 DOI 10.5195/jyd.2019.720

\section{Assessment of a Youth Livestock Sales Program}

Weikert, B., Hoover, T., Radhakrishna, R., \& Swinker, A. (2015). The factors that influence the involvement of youth in Pennsylvania 4-H extension district 16 livestock programs. Journal of Extension, 53(4). Retrieved from https://www.joe.org/joe/2015august/rb4.php

Williams, B., Thompson, J., Taylor, T., \& Sanders, K. E. (2010). The Impact of a youth development program on secondary students' career aspirations. Journal of Youth Development, 5(3), 75-88. doi: $10.5195 /$ jyd.2010.210

Workman, J. D., \& Scheer, S. D. (2012). Evidence of impact: Examination of evaluation studies published in the Journal of Extension. Journal of Extension, 50(2). [On-line] Retrieved from http://www.joe.org/joe/2012april/pdf/JOE_v50_2a1.pdf 